INTERNATIONAL JOURNAL OF CURRENT RESEARCH IN CHEMISTRY AND PHARMACEUTICAL SCIENCES

(p-ISSN: 2348-5213: e-ISSN: 2348-5221)

www.ijcrcps.com

DOI: $10.22192 /$ ijcrcps

Coden: IJCROO(USA)

Volume 7, Issue 5 - 2020

Research Article

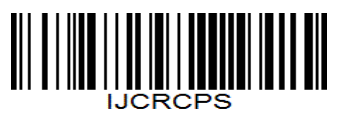

DOI: http://dx.doi.org/10.22192/ijcrcps.2020.07.05.001

\title{
Behavior and Quantification of Clopidogrel Bisulphate in Pure and Pharmaceutical Dosage Forms Using Differential Pulse Polarography With Static Mercury Drop Electrode
}

\author{
Abdul Aziz Ramadan ${ }^{1}$, Hasna Mandil ${ }^{2}$, Nidal Ashram ${ }^{3}$ \\ Department of Chemistry, Faculty of Science, University of Aleppo, Syria. \\ *1lE-mail:dramadan@scs-net.org ordramadan1946@gmail.com; \\ ${ }^{2}$ E-mail:promandil955@gmail.com \\ ${ }^{3}$ E-mail: Ashram88888@gmail.com
}

\begin{abstract}
Differential pulse polarographic analysis (DPPA) was applied by using static mercury drop electrode (SMDE) for quantification of clopidogrel bisulphate (CLPB) in pure and pharmaceutical dosage forms. The optimum conditions for the polarographic signal were determined and a study was made of the different parameters affecting the electrochemical process. The best definition of the analytical signals was found in di-sodium hydrogen phosphate buffer $(0.02 \mathrm{M})$ at $\mathrm{pH}$ 8.5. Under the optimum conditions, liner calibration graph, $\mathrm{I}_{\mathrm{p}}=\mathrm{f}\left(\mathrm{C}_{\mathrm{CLP}}\right)$ was obtained in the concentration ranges of $0.25 \mu \mathrm{M}\left(0.08055 \mu \mathrm{g} \cdot \mathrm{mL}^{-1}\right)$ to $30 \mu \mathrm{M}\left(9.6546 \mu \mathrm{g} \cdot \mathrm{mL}^{-1}\right)$ at -1278 to $-1312 \mathrm{mV}$ (versus $\mathrm{Ag} / \mathrm{AgCl}$ ) with relative standard deviations (RSD) did not exceed $2.2 \%$ for the concentrations of CLP $\left(0.0805 \mu \mathrm{g} \cdot \mathrm{mL}^{-1}\right)$. Regression analysis showed a good correlation coefficient $\left(\mathrm{R}^{2}=0.9999\right)$ between $\mathrm{I}_{\mathrm{p}}$ and concentration over the mentioned range. The limit of detection (LOD) and the limit of quantification (LOQ) were to be 0.010 and $0.030 \mu \mathrm{g} \cdot \mathrm{mL}^{-1}$, respectively. The proposed method was validated for linearity, precision and accuracy, repeatability, sensitivity (LOD and LOQ), robustness and specificity. The developed method is applicable for the determination of CLP in pure and different dosage forms in presence a same amount of aspirin (ASP) with average recovery of 98.9 to $101.8 \%$ and the results are in good agreement with those obtained by the HPLC reference method.
\end{abstract}

Keywords: Differential pulse polarography; Static mercury drop electrode, Clopidogrel. 


\section{Introduction}

Clopidogrel Bisulphate (CLPB), methyl(+)-(s)- $\alpha-$ (o-chlorophenyl) 6,7- dihydrothieno (3, 2-c) pyridine-5 (4H)- acetate bisulphate, is a new antiplatelet agent, and it is similar to ticlopidine in chemical structure (see scheme 1), its molecular weight of $419.8 \mathrm{~g} / \mathrm{mol}$ of CLPB (draw CLP is $321.8 \mathrm{~g} / \mathrm{mol})$ [1,2].

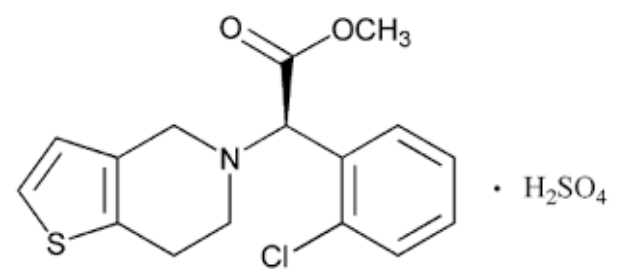

\section{Scheme 1 Chemical structure of clopidogrel bisulphate (CLPB)}

Clopidogrel is as a potent anti-platelet aggregation agent, has become available in the market. The medical properties, pharmaco dynamics, pharmacokinetics and various aspects of this compound, have been published [3-5].

The literatures for the quantification of clopidogrel were including potentiometric method [6-8] and voltammetry [9-15], spectrophotometry [16-18], and high performance liquid chromatography [19-20].

The construction and general performance characteristics of membrane potentiometric sensors responsive to the clopidogrel bisulphate drug are described. The sensors are based on the use of ion-association complexes of clopidogrel bisulphate (CLPB) with tungstosilicic acid haydrate, as exchange sites in a PVC matrix (Coated wire) (I), PVC silicon oxide nanoparticles (II) and graphine -nanographine oxide (III), The sensors show a fast, stable and near- Nernstian response for the mono and di charge cation and di charge anion of CLP over the concentration range $1 \times 10^{-5}-10^{-2} \mathrm{M}$ for (I), $1 \times 10^{-7}-10^{-3} \mathrm{M}$ for both (II) and (III) at $25^{\circ} \mathrm{C}$ over the pH range 1.4 3.7, $1.4-4.7$ and $1.4-10.2$ for CLP ( I , II and III ) sensors with slope of $54.39 \pm 0.4,30.19 \pm 0.4$ and $28.1 \pm 0.2$ respectively. The new sensors were used for the determination of CLP in tablets, Urine and Serum compared with standard method using UV and potentiometric titration [8].
A novel modified glassy carbon electrode based on poly aspartic acid- $\mathrm{Fe}_{3} \mathrm{O}_{4}$ nanoparticle/multiwalled carbon nanotubes composite (PAAFeNPs-MWCNTs/GCE) was developed and used as an efficient sensor for simultaneous determination of piroxicam (PRX) and clopidogrel (CLP) in the presence of uric acid (UA). The differential pulse voltammetry (DPV) results showed that under the optimal experimental conditions the obtained anodic peak currents were linearly proportional to concentration in the range of $0.2-80 \mu \mathrm{M}$ with a detection limit of $76 \mathrm{nM}$ for CLP [13].

The DNA binding properties of clopidogrel bisulphate, was examined by cyclic voltammetry, fluorescence and UV spectroscopy. The binding constant is calculated using absorbance and is found to be closer to that estimated in voltammetric measurements [14].

The effect of variation of concentration of aspirin on electrooxidation of clopidogrel bisulphate is studied by variation of scan rate and $\mathrm{pH}$. With increase in sweep rate, the anodic peak current increases linearly with correlation coefficient 0.9819 indicating the electrooxidation process to be diffusion controlled. Spectrophotometrically, absorption maximum of aspirin was found to be $223 \mathrm{~nm}$ and $275 \mathrm{~nm}$ while that of clopidogrel bisulphate was found to be $227 \mathrm{~nm}$. In vitro interactions were carried out in simulated intestinal juice and gastric juice with $\mathrm{pH} 1$ and 9 respectively. 
It was found that absorption maximum of aspirin remained at $223 \mathrm{~nm}$ while that of clopidogrel shifted to $203 \mathrm{~nm}$, confirming the interaction [15].

The static mercury drop electrode (SMDE) used successfully in polarographic analysis. The SMDE combines the features of the DME and HMDE: As with the DME, the drops are constantly renewed, but during the measurement the drop area is constant as in the HMDE case. In a subsequent voltage (U) sweep, the $\mathrm{Hg}$ drops are knocked off by the tapping mechanism after the time t.step set in the measurement mode. The SMDE is primarily used for sensitive measurements in which the surface of the mercury drop must be renewed for every measurement, but sensitive measurements decrease when get adsorption reaction on electrode. Further, less mercury is needed. On the other hand, the MME capillary is subjected to greater mechanical stress than in the SMDE case [21].

In the present research, differential pulse polarographic behavior and quantification of the clopidogrel in pure and pharmaceutical dosage forms using a static mercury drop electrode was applied. The method is easy, fast and sensitive for the determination of this compound in pure and in pharmaceuticals.

\section{Materials and Methods}

\section{Equipment and Materials}

A Metrohm 746 VA processor, A Metrohm 747 VA stand with a static mercury drop electrode (SMDE) as a working electrode, an auxiliary platinum electrode and a reference electrode, double junction type, $(\mathrm{Ag} / \mathrm{AgCl})$ saturated with a $3.0 \mathrm{M} \mathrm{KCl}$ solution and the three-electrode cell were used. All measurements were done at room temperature $25 \pm 5^{\circ} \mathrm{C}$. Highly pure nitrogen gas $(99.999 \%)$ was used for de-oxygenation. $\mathrm{pH}$ meter from radiometer company model ion check was used for the studying and monitoring the $\mathrm{pH}$ effects. The diluter pipette model DIP-1 (Shimadzu), having $100 \mu \mathrm{L}$ sample syringe and five continuously adjustable pipettes covering a volume range from 20 to $5000 \mu \mathrm{L}$ (model PIPTMAN P, GILSON), were used for preparation of the experimental solutions. An ultrasonic processor model Power Sonic 405 was used to sonicate the sample solutions. Electronic balance (Sartorius-2474; $\mathrm{d}=0.01 \mathrm{mg}$ ) was used for weighing the samples.

We used working reference standard of clopidogrel (98.5\%) was supplied by D.K. Pharma. Chem. Pvt. Ltd INDIA, (Mfg.11-2018, Exp. 11-2021). Lithium perchlorate trihydrate, diSodium hydrogen phosphate dodecahydrate, Sodium chloride, Sodium hydroxid, Perchloric acid $(70 \%)$, ortho-Phosphoric acid (85\%), Acetic acid $(100 \%)$, Boric acid (100\%) were of GR for analysis purchased from MERCK.

A commercial formulations (as tablets) were used for the analysis of CLP by using DPPA with SMDE electrode. The pharmaceutical formulations were subjected to the analytical procedures:

(1) Pharma Grel, F.C. Tablet, PHARMASYR, Damascus-SYRIA, each tablet contains: $75 \mathrm{mg}$ of CLP (Exp. 08.2022).

(2) Plaraz, F.C. Tablet, AL-RAZI, AleppoSYRIA, each tablet contains: $75 \mathrm{mg}$ of CLP and (Exp. 04.2022).

(3) Norgrel Plus, F.C. Tablet, UNIPHARMA, Damascus-SYRIA, each tablet contains: $75 \mathrm{mg}$ of CLP and $75 \mathrm{mg}$ ASPIRIN (Exp. 09.2020).

(4) Clopid, F.C. Tablet, EL-SAAD, AleppoSYRIA, each tablet contains: $75 \mathrm{mg}$ of CLP (Exp. 09.2022).

(5) Plofexine, F.C. Tablet, ASIA, AleppoSYRIA, each tablet contains: $75 \mathrm{mg}$ of CLP (Exp. 05.2020).

(6) Clotless, F.C. Tablet, APHAMEA, HamaSYRIA, each tablet contains: $75 \mathrm{mg}$ of CLP (Exp. 01.2021). 


\section{Standard stock solutions}

\section{A stock standard solution of clopidogrel bisulphate (1x10 ${ }^{-4}$ mol.L $\left.{ }^{-1}\right)$}

This solution was prepared by dissolving 42.63 $\mathrm{mg}$ from clopidogrel bisulphate in $100 \mathrm{~mL}$ methanol $\left(1 \times 10^{-3} \mathrm{~mol} . \mathrm{L}^{-1}\right)$, then dilute $10.000 \mathrm{~mL}$ from this solution to $100 \mathrm{~mL}\left(1 \times 10^{-4} \mathrm{~mol}^{-\mathrm{L}^{-1}}\right)$.

\section{Supporting electrolyte}

Britton robinson, $\mathrm{H}_{3} \mathrm{PO}_{4}-\mathrm{Na}_{2} \mathrm{HPO}_{4}$, lithium perchlorate, sodium chloride, borax, sodium acetate (HAc-NaAc) buffer 0.02 mol.L $^{-1}$ at $\mathrm{pH}$ (6.0-10.0) were used.

\section{Recommended Procedure}

The stock solutions were further diluted to obtain working solutions daily just before use in the ranges of clopidogrel: $0.1050,0.2100,0.4199$, $0.8398,1.6796,3.3592,5.0388,6.7184,8.3980$, 10.4975 and $12.5970 \mu \mathrm{g} . \mathrm{mL}^{-1}$ of CLPB (equivalent $0.08050 .1609,0.3218,0.6436$, $1.2873,2.5746,3.8618,5.1491,6.4363,8.0455$ and 9.6546 of CLP $\mu \mathrm{g} . \mathrm{mL}^{-1}$ ) or $0.25,0.50,1.00$, $2.00,4.00,8.00,12.00,16.00,20.00,25.00$ and $30.00 \mu \mathrm{mol} . \mathrm{L}^{-1}$ by using of the volumes: 0.0625 , $0.125,0.250,0.500,1.000,2.000,3.000,4.000$, $5.000,6.250$, and $7.500 \mathrm{~mL}$ from stock standard solutions $\left(1 \times 10^{-4}\right.$ mol. $\left.\mathrm{L}^{-1}\right)$ were transferred into 25 $\mathrm{mL}$ volumetric flask. $5.0 \mathrm{~mL}$ of supporting electrolyte was added, and diluted with double distilled water to the mark.

\section{Procedure for pharmaceutical formulations}

Contents of 20 tablets of each studied pharmaceutical formulations were weighted accurately, crushed to a fine powder and mixed well. Equivalent weight of contents of one tablet was solved in $50 \mathrm{~mL}$ methanol by using ultrasonic, filtered over a $100 \mathrm{~mL}$ flask and diluting to $100 \mathrm{~mL}$ with methanol, which content as the follows: $750 \mu \mathrm{g} \cdot \mathrm{mL}^{-1}$ for all studied pharmaceutical formulations content $75 \mathrm{mg} / \mathrm{tab}$.
These solutions were prepared daily by diluting $100 \mu \mathrm{L}(0.100 \mathrm{~mL})$ from stock solutions of pharmaceutical formulations into $25 \mathrm{~mL}$ volumetric flask, diluted with $\mathrm{H}_{3} \mathrm{PO}_{4}-\mathrm{Na}_{2} \mathrm{HPO}_{4}$ buffer $0.02 \mathrm{M}(\mathrm{pH} 8.5)$ to the mark (each solution contents $3.000 \mu \mathrm{g} . \mathrm{mL}^{-1}$ of CLP $\left(9.323 \times 10^{-6} \mathrm{M}\right)$.

\section{Analytical procedure}

$25 \mathrm{~mL}$ of working standard of clopidogrel or working solutions of pharmaceuticals was transferred to the cell. The solution was deoxygenated with $\mathrm{N}_{2}$ gas for $500 \mathrm{~s}$. The potential range studied was from -1050 to $-1500 \mathrm{mV}$ versus $\mathrm{Ag} / \mathrm{AgCl}$ with differential pulse polarographic analysis using static mercury drop electrode in the optimum conditions were applied.

\section{Results and Discussion}

\section{Differential pulse polarographic behavior}

The polarograms for concentration 0.25-30.0 $\mu \mathrm{mol} . \mathrm{L}^{-1}\left(0.105-12.5970 \mu \mathrm{g} . \mathrm{mL}^{-1}\right.$ of CLPB or 0.0805-9.6546 of CLP $\mu \mathrm{g} . \mathrm{mL}^{-1}$ ) in the optimal conditions (supporting electrolytes, $\mathrm{pH}$, scan rate, initial potential, final potential, etc.) using DPPA at SMDE were studied. The best definition of the analytical signals was found in $\mathrm{H}_{3} \mathrm{PO} 4-\mathrm{Na}_{2} \mathrm{HPO} 4$ $(0.02 \mathrm{M})$ buffer $(\mathrm{pH} 8.5)$ at -1278 to $-1312 \mathrm{mV}$ (versus $\mathrm{Ag} / \mathrm{AgCl}$ ).

\section{The effect of supporting electrolytes (buffer)}

The electrochemical behavior of clopidogrel was studied in various supporting electrolytes such as (Britton Robinson, di-sodium hydrogen phosphate dodecahydrate, sodium chloride, sodium acetate (HAc-NaAc), lithium perchlorate, borax buffers were studied at $\mathrm{pH}$ (6.0-10.0). The best definition of the analytical signals was found in di-sodium hydrogen phosphate dodecahydrate buffer $(\mathrm{pH}$ 8.5) at concentration $0.02 \mathrm{M}$. The effect of supporting electrolytes (buffer) on the $I_{p}$ and $E_{p}$ was studied. The values of $E_{p}$ were $-1247,-1279$, $-1283,-1284,-1305$ and $-1343 \mathrm{mV}$ for the mention buffers, respectively, see Figure 1. 


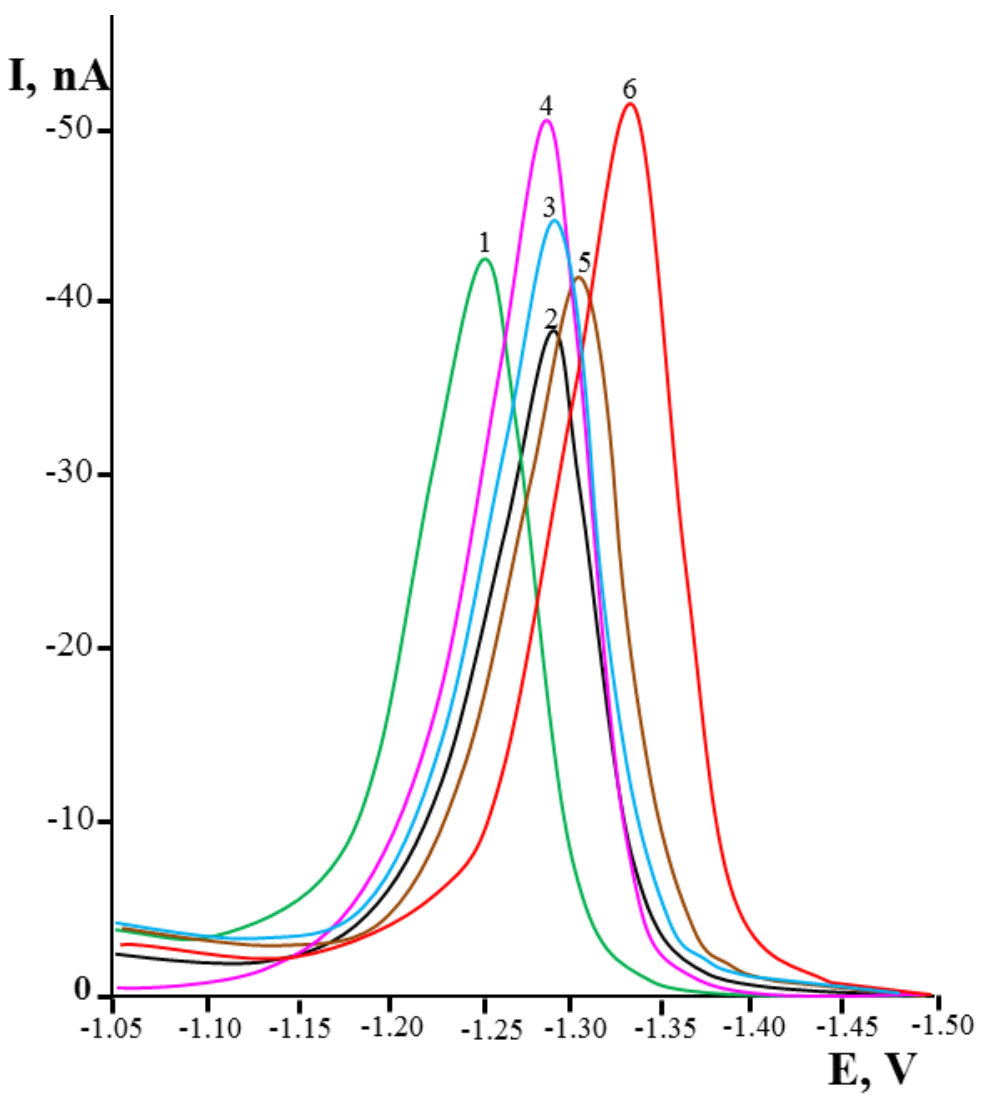

Fig.1: The effect of buffer solutions on polarograms of CLP $(12 \mu \mathrm{M})$ using DPPA at SMDE buffers $(0.02$ M) at $\mathrm{pH}$ 8.5: 1- Britton-Robinson, 2- $\mathrm{HAc}-\mathrm{NaAc}, 3-\mathrm{NaCl}$, 4- $\mathrm{Na}_{2} \mathrm{HPO}_{4} \cdot 12 \mathrm{H}_{2} \mathrm{O}$, 5- $\mathrm{LiClO}_{4} \cdot 3 \mathrm{H}_{2} \mathrm{O}$, 6$\mathrm{Na}_{2} \mathrm{~B}_{4} \mathrm{O}_{7}$ (Purge gas $\mathrm{N}_{2}$, purge time 500s, sweep rate $5 \mathrm{mV} / \mathrm{s}$, U. amplitude $-100 \mathrm{mV}$, t. meas $30 \mathrm{~ms}$, t. pulse $35 \mathrm{~ms}$, t. step $1.6 \mathrm{~s}$, U. step $8 \mathrm{mV}$, drop size 9 , temperature $25^{\circ} \pm 5^{\circ} \mathrm{C}$ ).

\section{The effect of $\mathrm{pH}$}

The influence of $\mathrm{pH}$ from 6.0 to 10.0 using disodium hydrogen phosphate dodecahydrate $(0.02$ $\mathrm{M})$ buffer on $\mathrm{I}_{\mathrm{p}}$ and $\mathrm{E}_{\mathrm{p}}$ was studied. The values of $\mathrm{I}_{\mathrm{p}}$ increase with increasing $\mathrm{pH}$ value of 6.0 to 8.0 , then become semi-fixed until $\mathrm{pH} 9.0$ and finally decrease until $\mathrm{pH} 10$. While $\mathrm{E}_{\mathrm{p}}$ values are growing a positive value from $-1363 \mathrm{mV}$ (when $\mathrm{pH}$ 6.0) to $-1284 \mathrm{mV}$ (when $\mathrm{pH}$ 9.0) then become semi-fixed until pH 10, see Figures 2,3. 
Int. J. Curr. Res. Chem. Pharm. Sci. (2020). 7(5): 1-13

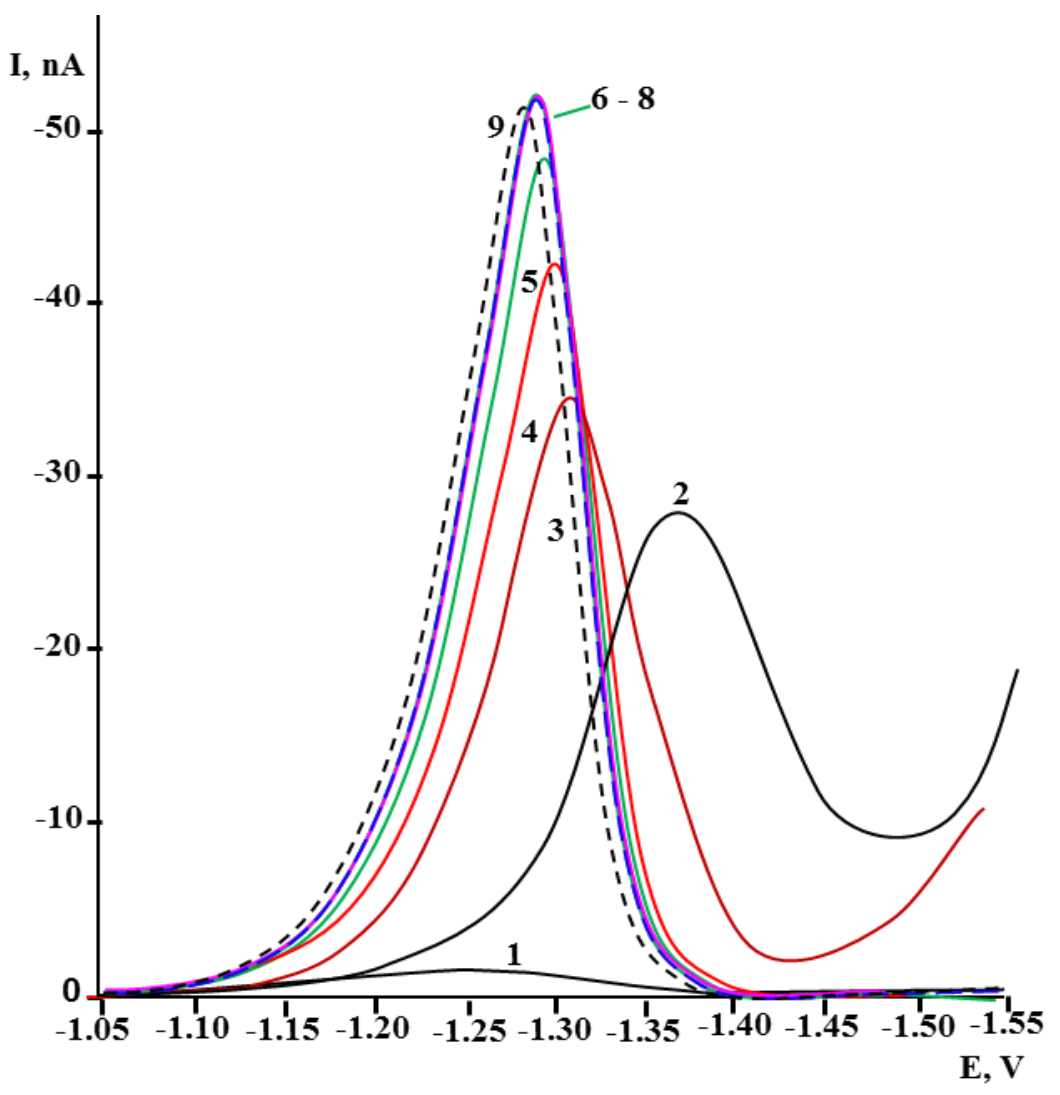

Fig.2: The effect of $\mathrm{pH}$ solution on polarograms of CLP $(12 \mu \mathrm{M})$ using DPPA at SMDE at pH: 1- electrolyte; 2- 6.00; 3- 6.75; 4- 7.00; 5- 7.50; 6- 8.00; 7- 8.50; 8- 9.00; and 9- $10.00\left(\mathrm{Na}_{2} \mathrm{HPO}_{4} .12 \mathrm{H}_{2} \mathrm{O}\right.$ $(0.02 \mathrm{M})$, Purge gas $\mathrm{N}_{2}$, purge time $500 \mathrm{~s}$, sweep rate $5 \mathrm{mV} / \mathrm{s}$, U. amplitude $-100 \mathrm{mV}$, drop size 9 , t. meas 30 $\mathrm{ms}$, t. pulse $35 \mathrm{~ms}$, t. step $1.6 \mathrm{~s}$, U. step $8 \mathrm{mV}$, temperature $25^{\circ} \pm 5^{\circ} \mathrm{C}$ ).
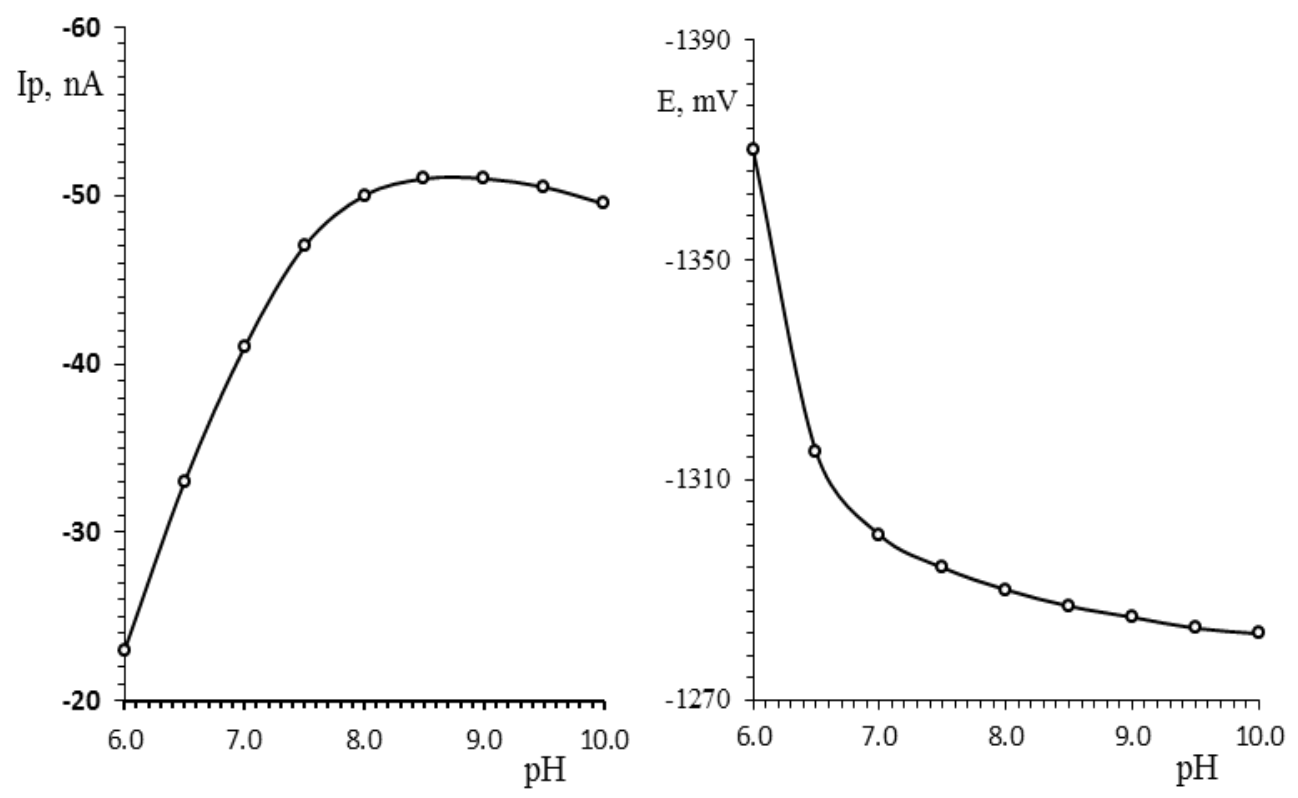

Fig.3: The effect of $\mathrm{pH}$ solution on $\mathrm{E}_{\mathrm{p}}$ and $\mathrm{I}_{\mathrm{p}}$ of CLP $(12 \mu \mathrm{M})$ using DPPA at SMDE containing buffer $\mathrm{Na}_{2} \mathrm{HPO}_{4} .12 \mathrm{H}_{2} \mathrm{O}\left(0.02 \mathrm{M}\right.$ ) (Purge gas $\mathrm{N}_{2}$, purge time $500 \mathrm{~s}$, sweep rate $5 \mathrm{mV} / \mathrm{s}$, U. amplitude $-100 \mathrm{mV}$, drop size 9 , t. meas $30 \mathrm{~ms}$, t. pulse $35 \mathrm{~ms}$, t. step $1,6 \mathrm{~s}$, U. step $8 \mathrm{mV}$, temperature $25^{\circ} \pm 5^{\circ} \mathrm{C}$ ). 


\section{The effect of negative pulse amplitude (U.ampl)}

The effect of negative pulse amplitude (U.ampl) between -10 to $-100 \mathrm{mV}$ on $\mathrm{I}_{\mathrm{p}}$ and $\mathrm{E}_{\mathrm{p}}, \mathrm{I}_{\mathrm{p}}$ linearly increases with increasing amplitude value until -100 mV. While $E_{p}$ stay semi-fixed. The value $-100 \mathrm{mV}$ was better than another's and Ip was the highest.

\section{The effect of initial and final potential}

The effect of initial and final potential on the $I_{p}$ and $E_{p}$ was studied. It was found that better initial potential was $-1050 \mathrm{mV}$ and better final potential was $-1500 \mathrm{mV}$.

\section{The effect of temperature and time}

The effect of temperature and time on the electrochemical behavior of CLP was studied at different values $\left(15-35^{\circ} \mathrm{C}\right.$ and $\left.5-60 \mathrm{~min}\right)$ by continuous monitoring of the $\mathrm{I}_{\mathrm{p}}$. It was found that, the value of $I_{p}$ was not affected by temperature between 20 to $30^{\circ} \mathrm{C}$ (the temperature at $25 \pm 5^{\circ} \mathrm{C}$ was used). The effect of waiting time was determined at laboratory ambient temperature $\left(25 \pm 5^{\circ} \mathrm{C}\right)$. It was found that, the value of $\mathrm{I}_{\mathrm{p}}$ was not affected by time between 5 to $60 \mathrm{~min}$.

\section{The effect of time pulse (t.pulse)}

The effect of time pulse $(35,40,50,60,70,80,90$ and $100 \mathrm{~ms}$ ) on polarograms was as the follows:
Ip decreases with increasing time pulse and Ep has become increasingly negative value (-1282 to $-1265 \mathrm{mV}$ ) with increasing t.pulse. The peak was more symmetrical and Ip was the highest when the t.pulse value was $35 \mathrm{~ms}$.

\section{The effect of time interval for voltage step (t.step)}

Ip linearly increases with increasing t.step (0.6, $0.8,1.2,1.6$ and $2.0 \mathrm{~s}$ ), while Ep remains fixed with increasing t.step. The value of the preferred t.step was $1.6 \mathrm{~s}$.

\section{The effect of measurement time (t.meas)}

$\mathrm{I}_{\mathrm{p}}$ increases with increasing t.meas. $(4,8,12,16$, $20,24,28,30$, and $32 \mathrm{~ms}$ ), while $\mathrm{E}_{\mathrm{p}}$ remains quasi-static. The value of the preferred t.meas. was $30 \mathrm{~ms}$.

\section{The effect of drop size}

$I_{p}$ increases with increasing drop size from 1 to 9 size, While $E_{p}$ stay semi-fixed with increasing drop size. The value of the preferred drop size was 9. The optimum parameters established for determination of CLP using DPPA on SMDE showed in Table 1.

Table 1: The optimum parameters established for determination of CLP using DPPA on SMDE.

\begin{tabular}{|l|c|}
\hline \multicolumn{1}{|c|}{ Parameters } & Operating modes \\
\hline Working electrode & Static Mercury Drop Electrode (SMDE) \\
Supporting electrolytes (buffer) & di-sodium hydrogen phosphate $0.02 \mathrm{M}$ \\
pH & 8.5 \\
solvent of clopidogrel & Methanol \\
Purge gas & Pure $\mathrm{N}_{2}$ \\
Purge time & $500 \mathrm{~s}$ \\
Initial potential & $-1050 \mathrm{mV}$ \\
Final potential & $-1500 \mathrm{mV}$ \\
Scan rate & $8 \mathrm{mV} / \mathrm{s}$ \\
t. meas & $30 \mathrm{~ms}$ \\
Value of pulse amplitude & $-100 \mathrm{mV}$ \\
t. pulse & $35 \mathrm{~ms}$ \\
t. step & $1.6 \mathrm{~s}$ \\
Drop size & 9 \\
Temperature of solution & $25^{\circ} \pm 5^{\circ} \mathrm{C}$ \\
\hline
\end{tabular}




\section{Calibration curves}

Calibration curves for the determination of CLP using differential pulse polarographic analysis on SMDE with negative amplitude in di-sodium hydrogen phosphate $(0.02 \mathrm{M})$ buffer at $\mathrm{pH} 8.5$ were applied. One peak was observed in the range -1278 to $-1312 \mathrm{mV}\left(\mathrm{E}_{\mathrm{p}}\right)$. The peak current $\left(\mathrm{I}_{\mathrm{p}}\right)$ was proportional to the concentration of CLPB over the ranges $0.1050-12.5970 \mu \mathrm{g} \cdot \mathrm{mL}^{-1}$ or 0.0805-9.6546 of CLP $\mu \mathrm{g} \cdot \mathrm{mL}^{-1}(0.250-30.000$ $\left.\mu \mathrm{mol} . \mathrm{L}^{-1}\right)$. The polarograms in the optimum conditions using DPPA at SMDE of CLP at different concentrations show in Figure 4. The regression equation were as the follows: $\mathrm{y}=-12.662 \mathrm{x}-0.1215, \mathrm{R}^{2}=0.9999 ; \mathrm{y}: \mathrm{I}_{\mathrm{p}}, \mathrm{nA}$ and $\mathrm{x}: \mathrm{C}_{\mathrm{CLP}}, \mu \mathrm{g} \cdot \mathrm{mL}^{-1}$ see Figure 4.

\section{Analytical results}

Determination of CLP using DPPA on SMDE in the optimum conditions using analytical curves, $\mathrm{I}_{\mathrm{p}}=\mathrm{f}\left(\mathrm{C}_{\mathrm{CLP}}\right)$, showed that the accuracy was ready over the ranges of CLP concentration between 0.0805-9.6546 of CLP $\mu \mathrm{g} \cdot \mathrm{mL}^{-1}$. The relative standard deviation (RSD) did not more than $2.2 \%$, see Table 2. Limit of detection (LOD) and limit of quantitation (LOQ) for the determination of CLP by this method were as the follows: 0.010 and $0.030 \mu \mathrm{g} \cdot \mathrm{mL}^{-1}$, respectively.

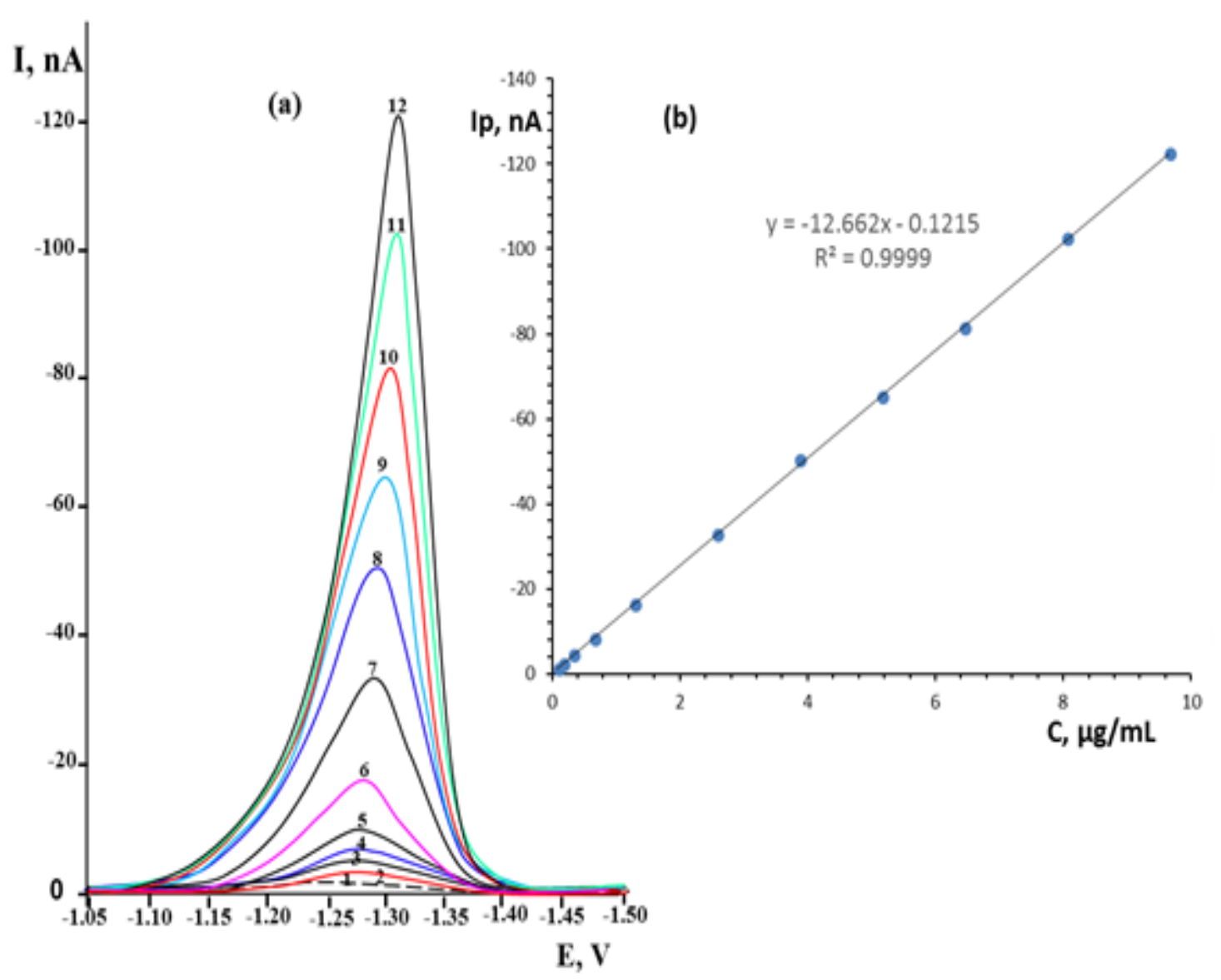

Fig.4: (a) The polarograms in the optimum conditions using DPPA on SMDE of CLP using DPPA at SMDE in $\mathrm{Na}_{2} \mathrm{HPO}_{4} .12 \mathrm{H}_{2} \mathrm{O} 0.02 \mathrm{M}$ buffer at concentrations: 1- electrolyte, 2- 0.0805, 3- 0.1609, 4- 0.3218, 5- 0.6436, 6- 1.2873, 7- 2.5746, 8- 3.8618, 9- 5.1491, 10- 6.4364, 11- 8.0455, 12- $9.6546 \mu \mathrm{g} . \mathrm{mL}^{-1}$, (b) Calibration curves for the determination of CLP (purge gas N2, purge time $500 \mathrm{~s}$, sweep rate $5 \mathrm{mV} / \mathrm{s}$, U. amplitude $-100 \mathrm{mV}$, t. meas $30 \mathrm{~ms}$, t. pulse $35 \mathrm{~ms}$, t. step $1.6 \mathrm{~s}$, U. step $8 \mathrm{mV}$, temperature $25^{\circ} \pm 5^{\circ} \mathrm{C}$ ). 
Table 2: Determination of clopidogrel using differential pulse polarographic analysis on SMDE with negative amplitude in di-sodium hydrogen phosphate $(0.02 \mathrm{M})$ buffer at $\mathrm{pH}$ 8.5.

\begin{tabular}{|c|c|c|c|c|c|c|}
\hline \multicolumn{2}{|c|}{ Taken $x_{i}$} & \multirow{2}{*}{$\begin{array}{c}\text { Found } \\
*_{\bar{x}}, \\
\mu g . m L^{-1}\end{array}$} & \multirow[b]{2}{*}{$\mathrm{SD}, \mu \mathrm{g} \cdot \mathrm{mL}^{-1}$} & \multirow{2}{*}{$\begin{array}{c}\frac{S D}{\sqrt{n}}, \\
\mu \mathrm{g} \cdot \mathrm{mL}^{-1}\end{array}$} & \multirow[b]{2}{*}{${ }_{x} \pm \frac{t . S D}{\sqrt{n}}, \boldsymbol{\mu g} \cdot \mathbf{m} \mathbf{L}^{-1}$} & \multirow[b]{2}{*}{ RSD\% } \\
\hline $\boldsymbol{\mu} \mathbf{M}$ & $\underset{(\text { CLP) }}{\mu g . m L^{-1}}$ & & & & & \\
\hline 0.25 & 0.0805 & 0.0817 & 0.0018 & 0.00805 & $0.0817 \pm 0.00223$ & 2.2 \\
\hline 0.50 & 0.1609 & 0.1634 & 0.0033 & 0.00146 & $0.1634 \pm 0.00406$ & 2.0 \\
\hline 1.00 & 0.3218 & 0.3282 & 0.0066 & 0.00294 & $0.3282 \pm 0.00815$ & 2.0 \\
\hline 2.00 & 0.6436 & 0.6295 & 0.0120 & 0.00535 & $0.6295 \pm 0.01485$ & 1.9 \\
\hline 4.00 & 1.2873 & 1.2787 & 0.0230 & 0.01029 & $1.2787 \pm 0.02858$ & 1.8 \\
\hline 8.00 & 2.5746 & 2.5735 & 0.0438 & 0.01957 & $2.5735 \pm 0.05432$ & 1.7 \\
\hline 12.00 & 3.8618 & 3.9628 & 0.0634 & 0.02836 & $3.9628 \pm 0.07872$ & 1.6 \\
\hline 16.00 & 5.1491 & 5.1499 & 0.0824 & 0.03685 & $5.1499 \pm 0.10230$ & 1.6 \\
\hline 20.00 & 6.4364 & 6.4246 & 0.0964 & 0.04310 & $6.4246 \pm 0.11964$ & 1.5 \\
\hline 25.00 & 8.0455 & 8.0781 & 0.113 & 0.05058 & $8.0781 \pm 0.14041$ & 1.4 \\
\hline 30.00 & 9.6546 & 9.6608 & 0.145 & 0.06481 & $9.6608 \pm 0.1800$ & 1.5 \\
\hline
\end{tabular}

\section{Applications}

Many applications for the determination of clopidogrel in some Syrian pharmaceutical preparations (in presence a same amount aspirin) using differential pulse polarographic analysis on static mercury drop electrode with negative amplitude in di-sodium hydrogen phosphate 0.02 $\mathrm{M}$ buffer $\mathrm{pH} 8.5$ according to the optimal conditions were proposed. The amount (m) of CLP in one tablet was calculated from the following relationship: $m=h . m$ ', where: $m^{\prime}$ is the amount of CLP in tablet calculated according to the regression equation of calibration curve, $h$ conversion factors are equal to 25 for all pharmaceuticals content $75 \mathrm{mg} / \mathrm{tab}$. The results of quantitative analysis for CLP in pharmaceutical preparations were summarized in Table 3. The proposed method was simple, direct and successfully applied to the determination of CLP in pharmaceuticals without any interference from excipients. Average assay ranged between 98.9 to $101.8 \%$. The results obtained by this method agree well with the contents stated on the labels and were validated by RP-HPLC method [19]. Therefore, the presented method can be recommended for routine analysis of CLP in pharmaceutical formulations. 
Int. J. Curr. Res. Chem. Pharm. Sci. (2020). 7(5): 1-13

Table 3: Determination of CLP in some Syrian pharmaceutical preparations using DPPA on SMDE with negative amplitude di-sodium hydrogen phosphate $0.02 \mathrm{M}$ buffer $\mathrm{pH} 8.5$ according to the optimal conditions.

\begin{tabular}{|c|c|c|c|c|c|}
\hline Commercial name & $\begin{array}{c}\text { Label Claim of } \\
\text { CLP, mg/tab. }\end{array}$ & $\begin{array}{c}\text { *Mean } \\
\pm \text { SD } \\
\text { (as CLP), } \\
\text { mg/ tab. }\end{array}$ & RSD\% & Assay \% & $\begin{array}{c}\text { * (Assay \%), } \\
\text { by HPLC [19] }\end{array}$ \\
\hline $\begin{array}{c}\text { Pharma GreL, } \\
\text { F.C.Tablet } \\
\text { PHARMASYR, }\end{array}$ & 75 & 74.4 & 2.2 & 99.2 & 99.0 \\
\hline $\begin{array}{c}\text { Plaraz, } \\
\text { F.C. Tablet } \\
\text { AL-RAZI }\end{array}$ & 75 & 76.2 & 2.2 & 101.6 & 100.9 \\
\hline $\begin{array}{c}\text { Norgrel Plus, } \\
\text { F.C. Tablet, } \\
\text { UNIPHARMA }\end{array}$ & 75 & 75.6 & 2.1 & 100.8 & 101.0 \\
\hline $\begin{array}{c}\text { Clopid, } \\
\text { F.C. Tablet, } \\
\text { EL-SAAD }\end{array}$ & 75 & 74.2 & 2.2 & 98.9 & 99.5 \\
\hline $\begin{array}{l}\text { Plofexine, } \\
\text { F.C. Tablet, } \\
\text { ASIA, }\end{array}$ & 75 & 76.5 & 2.1 & 102.0 & 101.5 \\
\hline $\begin{array}{c}\text { Clotless, } \\
\text { F.C. Tablet, } \\
\text { APHAMEA }\end{array}$ & 75 & 76.3 & 2.1 & 101.7 & 101.8 \\
\hline
\end{tabular}

\section{Method validation}

The developed method for simultaneous estimation of CLPB has been validated in accordance with the International Conference on Harmonization guidelines (ICH) [22].

\section{Selectivity}

Several other components were examined under the conditions that had been optimized for clopidogrel determination. The results show that aspirin did not interfere when present at same amount with clopidogrel.

\section{Linearity}

Several aliquots of standard stock solution of CLPB were taken in different $25 \mathrm{~mL}$ volumetric flasks such that their final concentrations were 0.1050-12.5970 $\mu \mathrm{g} . \mathrm{mL}^{-1}$ of CLPB or 0.08059.6546 of CLP $\mu \mathrm{g} . \mathrm{mL}^{-1}\left(0.250-30.000 \mu \mathrm{mol} . \mathrm{L}^{-1}\right)$ for CLPB using DPPA at SMDE in di-sodium hydrogen phosphate $0.02 \mathrm{M}$ buffer at $\mathrm{pH} 8.5$. Linearity equation obtained was: $y=-12.662 x$ -0.1215 , for the mentioned range $\left(\mathrm{R}^{2}=0.9999\right)$.

\section{Precision and Accuracy}

The precision and accuracy of proposed method was checked by recovery study by addition of standard drug solution to pre-analyzed sample solution at three different concentration levels $(80 \%, 100 \%$ and $120 \%)$ within the range of linearity for CLP. The basic concentration level of sample solution selected for spiking of the CLP standard solution was $5.1491 \mu \mathrm{g} \cdot \mathrm{mL}^{-1}$. The proposed method was validated statistically and through recovery studies, and was successfully applied for the determination of CLP in pure and dosage forms with percent recoveries ranged from $99.3 \%$ to $101.4 \%$, see Table 4 . 
Table 4: Results of recovery studies

\begin{tabular}{|c|c|}
\hline Level & Recovery\% \\
\hline $80 \%$ & 99.3 \\
$100 \%$ & 100.9 \\
$120 \%$ & 101.4 \\
\hline$(\mathrm{n}=5)$.
\end{tabular}

\section{Repeatability}

The repeatability was evaluated by performing 10 repeat measurements for $5.1491 \mu \mathrm{g} \cdot \mathrm{mL}^{-1}$ of CLP using the studied DPPA at SMDE di-sodium hydrogen phosphate $0.02 \mathrm{M}$ buffer $\mathrm{pH} 8.5$ under the optimum conditions. The found amount of CLP $(\overline{\mathbf{x}} \pm \mathrm{SD})$ was $5.1499 \pm 0.081 \mu \mathrm{g} \cdot \mathrm{mL}^{-1}$ and the percentage recovery was found to be $100.02 \pm 1.6$. These values indicate that the proposed method has high repeatability for CLP analysis.

\section{Sensitivity (limit of detection [LOD] and limit of quantitation [LOQ])}

The sensitivity of the presented method was evaluated by determining the LOD and LOQ. The values of LOD and LOQ for CLP are 0.010 and $0.030 \mu \mathrm{g} \cdot \mathrm{mL}^{-1}$, respectively.

\section{Robustness}

The robustness of the method adopted is demonstrated by the constancy of the current peak $\left(\mathrm{I}_{\mathrm{P}}\right)$ with the deliberated minor change in the experimental parameters such as the change in the concentration of excipients, temperature $\left(25 \pm 5^{\circ} \mathrm{C}\right), \mathrm{pH}(8.5 \pm 0.20)$, and $\mathrm{C}_{\text {elect }}(0.02 \pm 0.002$ mol. $\left.\mathrm{L}^{-1}\right)$ and reaction waiting time $(10 \mathrm{~min})$, see Table 5. Indicates the robustness of the proposed method. $\mathrm{I}_{\mathrm{p}}$ was measured and assay was calculated for five times.

Table 5: Robustness of the proposed DPPA method at SMDE for determination of clopidogrel.

\begin{tabular}{|c|c|}
\hline Experimental parameter variation & $\begin{array}{c}\text { Average recovery (\%)* } \\
\mathrm{C}_{\mathrm{CLP}}=3.8618 \mu \mathrm{g} \cdot \mathrm{mL}^{-1}\end{array}$ \\
\cline { 2 - 2 } & \\
\hline Temperature & 99.5 \\
$20^{\circ} \mathrm{C}$ & 100.7 \\
$25^{\circ} \mathrm{C}$ & 101.0 \\
$30^{\circ} \mathrm{C}$ & \\
$\mathrm{pH}$ & 99.9 \\
8.3 & 100.0 \\
8.7 & 99.8 \\
\hline $\mathrm{C}_{\mathrm{Na}_{2} \mathrm{HPO}_{4}}$ & 99.7 \\
$0.018 \mathrm{~mol} / \mathrm{L}$ & \\
$0.022 \mathrm{~mol} / \mathrm{L}$ & 99.8 \\
\hline reaction time & 99.9 \\
$10 \mathrm{~min}$ & 100.0 \\
\hline $30 \mathrm{~min}$ & \\
\hline $60 \mathrm{~min}$ & \\
\hline
\end{tabular}




\section{Specificity}

The specificity of the method was ascertained by analyzing standard CLPB in presence of excipients. These findings prove that the suggested methods are specific for determination of the investigated drugs without interference from the coformulated adjuvants.

\section{The homogenization of tablets}

The homogenization of tablets in terms of the weight and the amount of drug was studied. It found that the mean weight tablets were $0.2030 \pm$ 0.0040 g (i.e. $\pm 2.0 \%$ ), $0.3068 \pm 0.0053$ g (i.e. $\pm 1.7 \%$ ), $0.6864 \pm 0.0096$ g (i.e. $\pm 1.4 \%$ ), $0.1850 \pm$ 0.0040 g (i.e. $\pm 2.2 \%$ ), $0.4258 \pm 0.0069$ g (i.e. $\pm 1.6 \%$ ) and $0.2117 \pm 0.0054$ g (i.e. $\pm 2.6 \%$ ) for Pharma Grel, Plaraz, Norgrel Plus, Clopid, Plofexine and Clotless (75 mg/tab. of CLP). And amount of drug in the capsule was $75.00 \pm 1.4 \mathrm{mg}$ (i.e. $\pm 1.9 \%$ ), $75.00 \pm 1.3 \mathrm{mg}$ (i.e. $\pm 1.7 \%$ ), $75.00 \pm$ $1.1 \mathrm{mg}$ (i.e. $\pm 1.5 \%$ ), $75.00 \pm 1.6 \mathrm{mg}$ (i.e. $\pm 2.1 \%$ ), $75.00 \pm 1.2 \mathrm{mg}$ (i.e. $\pm 1.6 \%$ ), and $75.00 \pm 2.0 \mathrm{mg}$ (i.e. $\pm 2.7 \%$ ), for the mentioned drugs, respectively; which shows that homogeneity of tablets is acceptable.

\section{Conclusion}

Electrochemical behavior and DPPA of CLPB in pure form and in pharmaceutical preparations using SMDE with $0.02 \mathrm{M}$ di-sodium hydrogen phosphate buffer $\mathrm{pH} 8.5$ according to the optimal conditions was applied. One reduction peak was observed. $I_{p}$ is linear over the range 0.0805 9.6546 $\mu \mathrm{g} . \mathrm{mL}^{-1}\left(0.250-30.000 \mu \mathrm{mol} . \mathrm{L}^{-1}\right)$. The relative standard deviation did not exceed $2.2 \%$ for the concentration $0.0805 \mu \mathrm{g} \cdot \mathrm{mL}^{-1}$ of CLP. Regression analysis showed a good correlation coefficient $\quad\left(\mathrm{R}^{2}=0.9999\right)$ between $\mathrm{I}_{\mathrm{p}}$ and concentration over the mentioned range. The proposed method was successfully applied to the direct analysis of CLP in pharmaceutical formulations without any interference from excipients and with adequate accuracy and sensitivity without any pre-separation such as extraction.

\section{References}

1. Budavari S., 2011. "The Merck Index" 13th Ed. Merck \& Co. Inc. 856.

2. Henein W., 2006. "Atlas 2 everything about drugs from A to Z". Nobar publisher. 282.

3. Alesci J.P., Victorino A., 2013. Clopidogrel: pharmacology, clinical uses and adverse effects, Nova Science Pub Inc; UK.

4. Mostafa A.M.A., 2016. clopidogrel personalization: Pharmacogenetics and pharmacometabonomics: A Review of the Literature, LAP Lambert Academic Publishing.

5. Anderson J.L., Morrow D.A., 2017. Acute myocardial infarction. The New England Journal of Medicine. 376(21):2053-2064.

6. Bin Ibrahim S.F., Alarfaj N.A., Aly F.A., 2012. "Determination of clopidogrel bisulfate using ion-selective electrodes in bulk, pharmaceutical formulation and in biological fluids". J.American Science. 8:276-283.

7. Khorshid A.F., 2014. "Determination of clopidogrel bisulphate in Plavix tablet and human biological fluids utilizing chemically modified carbon paste sensor". J. Bioproces Biotechniq. 4:1-9.

8. Haydar O.E., Khaleel A.I., Muhammed, K.O., 2019. "New electrodes for determination of clopidogrel- bisulphate".JUG.10: 55-69.

9. Dizavandi Z.R., Aliakbar A., Sheykhan M., 2017. "Electrochemical determination of clopidogrel using $\mathrm{Bi}_{2} \mathrm{O}_{3}$-Pp-AP/GCE by differential pulse voltammetry in pharmaceutical productions". J. Electroanalytical Chemistry. 17:1-31.

10. Mohammadi A., Barin S.M., Naeemy A., 2012. "Determination of clopidogrel using a graphite electrode modified by multi-walled carbon nanotube/ poly ortho aminophenol nanocomposite film". Research in Phamaceutical Science. 7:S645.

11. Nascimento L.O., Scremin J., Mattos G.J., Gomes A., Clausen D.N., Sartori E.R., 2019. "A Novel strategy for quantifying clopidogrel using square-wave voltammetry and a borondoped diamond film". Electroanalysis. 31:1-8.

12. Mladenovic A.R., Jovanovic V.M., Petrovic S.D., Mijin D.Z., Drmanic S.Z., Ivic M.L., 2013. "Determination of clopidogrel using 
square wave voltammetry at a gold electrode". J. Serb. Chem. Soc. 78:2131-2140.

13. Babaei A., Afrasiabi M., Moghanian H., 2017. "A new sensor based on the glassy carbon electrode modified with poly aspartic acid$\mathrm{Fe}_{3} \mathrm{O}_{4}$ nanoparticle/ multi-walled carbon nanotubes composite for a selective simultaneous determination of piroxicam and clopidogrel in the presence of uric acid. Anal. Bioanal. Electrochem. 6: 741-761.

14. Malini S., Raj, K., Sennappan M., 2018."Electrochemical and spectroscopic studies of interaction of clopidogrel bisulphate with calf thymus DNA". Asian Journal of Chemistry. 30: 129-132.

15. Raj K., Malini S., 2017. "Cyclic voltammertic studies of in vitro interaction of clopidogrel bisulphate and aspirin". Materials Today. 5:22390-22398.

16. Abdul Sattar M.D., Rao U.U., Priyanka M., Kiran K.B., Sudha Ch.S., kumar G.V., 2014. "Method development and validation for the estimation of clopidogrel in tablet dosage form by UV spectrophotometric method". International Journal of Research and Novel Science. 1:171-175.

17. Mishra P., Dolly A., 2006. "Simultaneous determination of clopidogrel and aspirin in pharmaceutical dosage forms". J. Pharm. Sci. 68:365-368.

18. Ayad M.M., Abdellatef H.E., Hosny M.M., Sharaf Y.A., 2015. "Determination of pipazethate hydrochloride, fenoterol hydrobromide and clopidogrel hydrogen sulphate using citrate-capped gold nanoparticles". JCPR. 7: 68-74.

19. Shrivastava P.K., Basniwal P.K., Deepti J., Shrivastava S.K., 2008. "Concurrent estimation of clopidogrel bisulphate and aspirin in tablets by validated RP-HPLC Method". Indian J. Pharm. Sci. 70:667-669.

20. Sahoo N.K., Sahu M., Rao P,S., Indira J.N., Rani S.N., Ghosh G.K., 2014. "Validation of assay for bulk clopidogrel and for some tablet forms by reverse-phase high-performance liquid chromatography". J. Taibah Univ. Sci. 59:1-6.

21. Anderson J.E., Bond A.M., Jones R.D., 1981. "Differential Pulse Polarography at the Static Mercury Drop Electrode". Anal. Chem. 53 (7): 1016-1020.

22. ICH: Proceedings of the International Conference on Harmonization of Technical Requirement of Registration of Pharmaceuticals for Human Use (ICH Harmonized Tripartite Guidelines), 2005.

\begin{tabular}{|c|l|}
\hline \multicolumn{2}{|c|}{ Access this Article in Online } \\
\hline Q & Website: \\
\hline & www.ijcrcps.com \\
\hline Quick Response Code & \\
\hline \multicolumn{2}{|c|}{ DOI: 10.22192 /ijcrcps.2020.07.05.001 } \\
\hline
\end{tabular}

How to cite this article:

Abdul Aziz Ramadan, Hasna Mandil, Nidal Ashram. (2020). Behavior and Quantification of Clopidogrel Bisulphate in Pure and Pharmaceutical Dosage Forms Using Differential Pulse Polarography With Static Mercury Drop Electrode. Int. J. Curr. Res. Chem. Pharm. Sci. 7(5): 1-13.

DOI: http://dx.doi.org/10.22192/ijcrcps.2020.07.05.001 